\title{
A different vision for uninterruptible load using hybrid solar-grid energy
}

\author{
Mohamed Ibrahim A. Arafa, El-Sayed Soliman A. Said \\ Department of Electrical Engineering, Faculty of Engineering Al-Azhar University, Egypt
}

\begin{tabular}{l} 
Article Info \\
\hline Article history: \\
Received Oct 15, 2018 \\
Revised Nov 11, 2018 \\
Accepted Dec 3, 2018 \\
\hline
\end{tabular}

Keywords:

ATS

Batteries

Charge controller

Inverter

Photovoltaic

PLC

Private grid

Public grid

\begin{abstract}
Attempting to reduce the existing electricity consumption bill, as well as the stability and non-outage grid recharge with the lowest possible cost and suitable quality, is one of the most important goals for those interested in energy around the world. This paper study the circumstances surrounding the Egyptian society to find the best solutions to a achieved this goal, and it was found that solar energy is one of the best alternatives available for energy. Firstly, will be study the electricity consumption bill, slice prices and a program were made to calculate the consumption invoice moreover another program for quick estimation to the proposed solar system. The proposed system provides a smart integration between the solar system and grid, where the supply sustainability and the optimal cost are considered. This configuration allows the two sources separately or simultaneously supply the loads depending on photovoltaic extracted energy. Operational analysis of the proposed system will be discussed in this paper. The proposed system consists of solar cells, charge controller, batteries and inverter plugged to automatic transfer switches (ATS) using Programmable Logic Control (PLC). The system grantee a safe and reliable load feeding independently on the grid status. The system durability is the most depicted feature through the modelling and experimentally results. A typical case studies for about four years of non-outages photovoltaic-grid hybrid supply (the implemented system) will be presented and discussed
\end{abstract}

Copyright $@ 2019$ Institute of Advanced Engineering and Science. All rights reserved.

\section{Corresponding Author:}

Mohamed Ibrahim A. Arafa,

Department of Electrical Engineering,

Al-Azhar University, Al Nsrst. Cairo, Egypt.

E-mail: marafa_marafa@yahoo.com

\section{INTRODUCTION}

Energy challenge has become the most effective one in this century and environmentally friendly solutions in accompanied with a stable grid are becoming prominent. This paper proposes a configuration for a hybrid photovoltaic non-outages grid energy system. Looking for a natural environment without pollutants and sustainable energy solutions to preserve our own for the future generations [1]. Other than hydro power, wind and photovoltaic energy holds the most potential to meet our energy demands alone, wind energy is capable of supplying large amounts of power but its presence is highly unpredictable as it can be here one moment and gone in another, moreover it high cost. Solar energy is present throughout the day but the solar irradiation levels vary due to the sun intensity and unpredictable shadows cast by clouds, birds, trees, etc. [2], [3]. Now the cost of solar power is lower compared to the previous time. The world map for solar radiation

Morever, rate and availability in Egypt and the world urged us for use [4], [5].

the price of producing solar energy is becoming lower than before due to the frequent uses for it as shown in Figure 1. Allot of people use this particular clean energy after the sharply increasing in the accounting slice of energy. The common inherent drawback of wind and photovoltaic systems are their intermittent natures that make them unreliable, so it is important to be controlled as well as integrated with other more sources as 
batteries [7], [8]. Two experiments with different specification was implemented, the first experiment using 520-Watt polycrystalline photocells and 20A/24DCV PWM charge controller produced 2600 W/Day, the second experimental using 520-Watt mono-crystalline photocells and 20A/24DCV MPPT charge controller produced $3120 \mathrm{Watt} /$ day, more different kinds of loads as lights, motors, compressors, etc. to obtain accurate results. The second experience was the best it efficient than the first experiment by more than $17 \%$ of the first experiment.

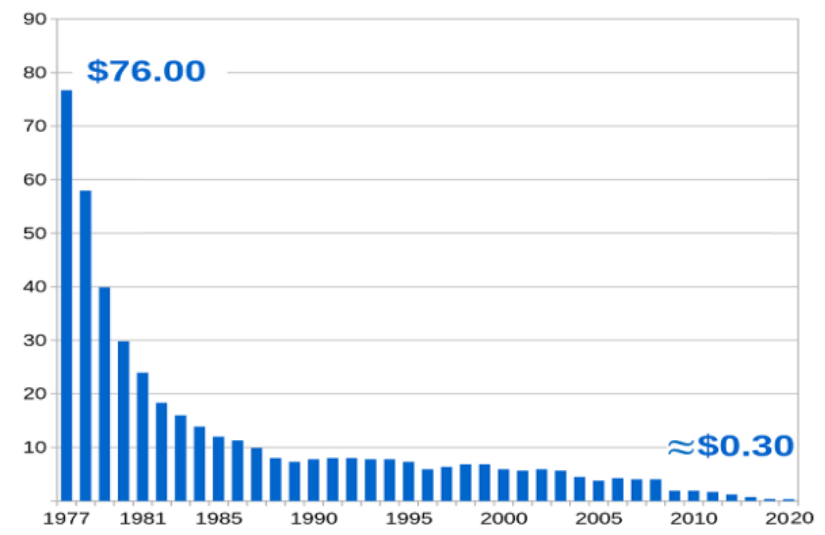

Figure 1. Price history of silicon PV cells

\section{THE MODEL OF THE PROPOSED SOLAR ENERGY CONVERSION SYSTEM}

The model of the proposed non outages hybrid gridphotovoltaic solar energy system consists of the PV solar panels, charge controller, batteries bank, PLC controlled ATS panel and inverter as shown in Figure 2. The system behaves as a load demand optimizer, where the load can fully be supplied by the solar energy in case of the public grid outages [10], [11].

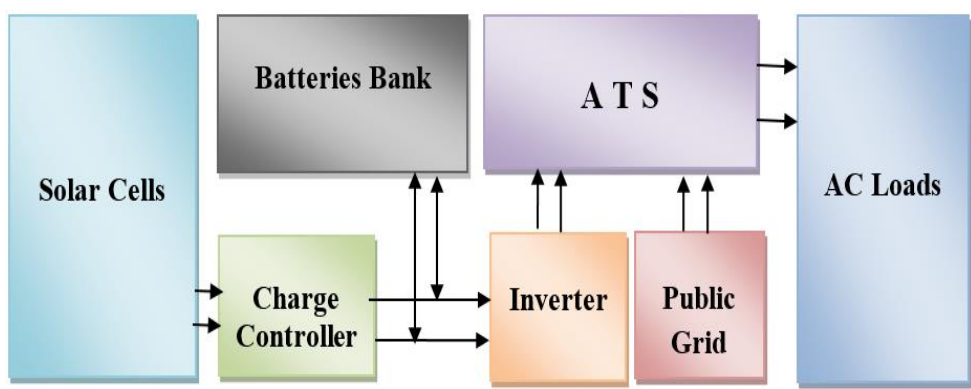

Figure 2. Block diagram of the proposed solar energy system connect to the public grid

\section{PROPOSED LOAD MAPPING AND MANAGEMENT FOR HOME}

Indeed, the ATS has fixed operation profile, and it can be sufficient for several limited needs application. To extend the ATS functionality the PLC look like a suitable solution for dynamic (programmable) ATS system. Programmable ATS controller allows to make an integrated system of domestic energy management depending on the accumulation between the solar and the public utility grid. The system considers that the homeor shops can be divided into subsectionsaccording to needs or emergency loads sections as example for children, grandfather and grandmotheras shown in Figure 3 or shops as general lighting, emergency corridors, surveillance, cameras and counters Section 1 will depend mainly on the solar energy; the other two sections are fed from solar or public utility grid automatically through programmable ATS refer to some conditions [12]. 


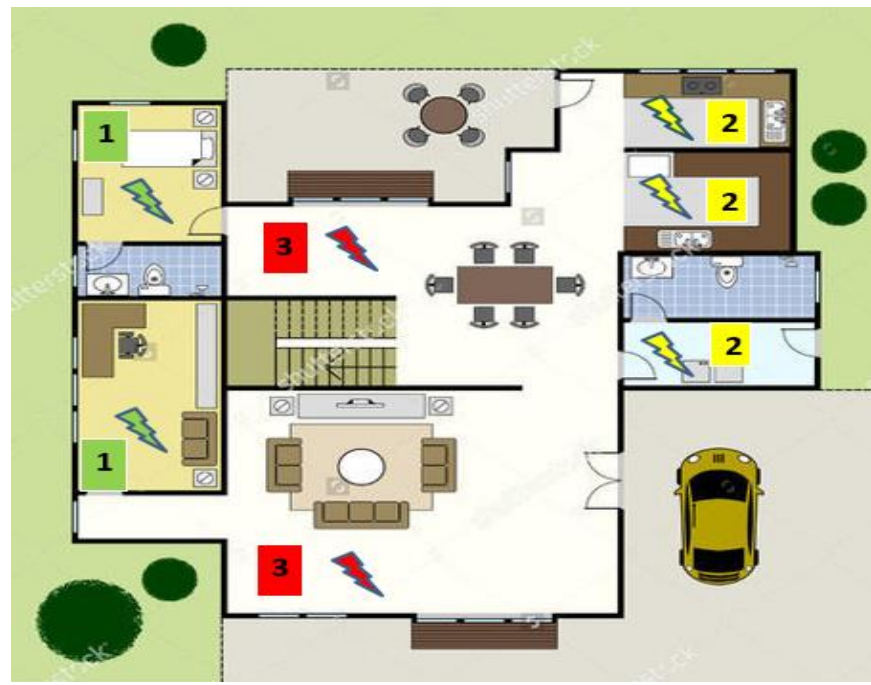

Figure 3. Apartment proposed sections

The system is designed to switch the source automatically as shown in Table 1. In case of the outage's public utility grid K1, K3, and K5 contactors are switched OFF then the solar energy contactors K2, $\mathrm{K} 4$, and $\mathrm{K} 6$ are switched $\mathrm{ON}$.

In case of no-solar energy, all the loads will be automatically connected to the public grid. However, the system is automated, the whole system manual switching is provided. Tabulation the design rules for operating and controlling the three different sections are explored in Table 1.

Table 1. PLC status design

\begin{tabular}{ccccccc}
\hline \multirow{2}{*}{ PLC Switches } & \multicolumn{2}{c}{ Section 1 } & \multicolumn{2}{c}{ Section 2} & \multicolumn{2}{c}{ Section 3} \\
& $K 1$ & $K 2$ & $K 3$ & $K 4$ & $K 5$ & $K 6$ \\
\hline No-utility & OFF & ON & OFF & ON & OFF & ON \\
No-solar & ON & OFF & ON & OFF & ON & OFF \\
Automatic & OFF & ON & ON & OFF & ON & OFF \\
Manual & ON/OFF & ON/OFF & ON/OFF & ON/OFF & ON/OFF & ON/OFF \\
No-utility No-solar & OFF & OFF & OFF & OFF & OFF & OFF \\
\hline
\end{tabular}

The solar energy system integrated with public grid through programmable ATS achieveeasiness to changing the electrical feeding to localized loads of this work ATS control panel and solar panels as shown in Figure 4.
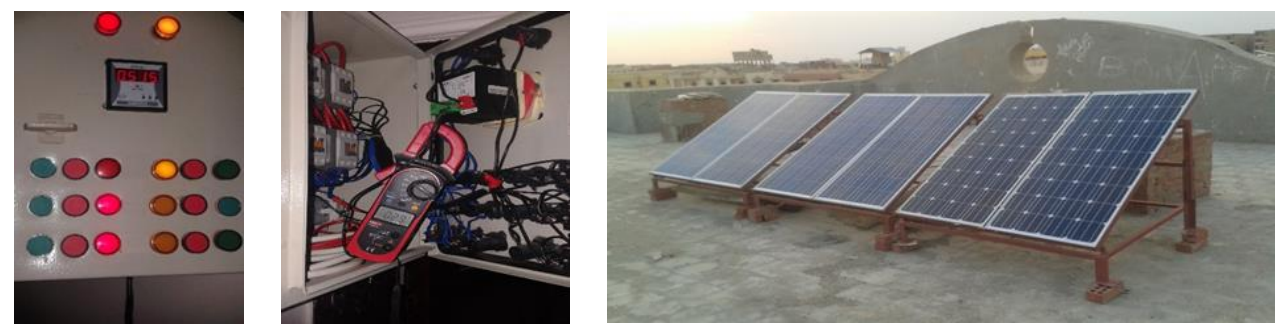

Figure 4. A T S control panel and solar panels

\section{PERFORMANCE PARAMERTER OF HOME SOSLAR SYSTEM}

The rated and the prices of the system components at 2014 are listed in Table 2 The duration of full loaded system has been exprementaly determined by a full load operation and fully OFF Grid. The system can grants a successfully load operation for $12 \mathrm{Hrs}$. However the non-outages supply demandes is the most dominat aim of this work, one can consider a partly non-outages supplies.For axample the non interruptable 
supply duration of the proposed system can be extreemly extended with a smart load mangement system (LMS). The system output current was 6 Ampare within the full load duration as well as $220 \mathrm{~V}$ system output voltage. It can successfully feed the full non outage loads for a lot ofhours. Cost optimization has been considered by transferring part of the loads to the solar energy system to be in a lower accounting slice.

Table 2. The prices of the solar energy system components

\begin{tabular}{ccccc}
\hline No. & Statement & Qty. & Characteristic & Price in EGP \\
\hline 1 & Solar cell & 6 & $130 \mathrm{~W}$ & 3900 \\
2 & Charge controller & 1 & $30 \mathrm{~A}$ & 140 \\
3 & Inverter & 1 & $1500 \mathrm{~W}$ & 800 \\
4 & Battery & 2 & $150 \mathrm{~A} / \mathrm{Hr}$ & 2140 \\
5 & ATS (PLC) & 1 & - & 2000 \\
6 & Els. & - & - & 220 \\
& & Total & & 9000 \\
\hline
\end{tabular}

The lower cost of the proposed system infera structure and long life time are some salient features of this system.Through about 6.4 years the system can succeuffly recover his cost. Furthrmore, in case of consumption higher than $1000 \mathrm{KW}$ monthly, the system cost will recoveed through 3.8 years

\section{CATEGORIES FOR ENERGY LOADS CONSUMPTION SYSTEM}

There are different categories forenergy consumption of power system such as residence, commercial, industrial and/or agricultural as shown in Figure 5. Each type of this consumption is divided into slices. These slices were worked out to try to help the first tranches to low the suffering of low-income citizens. This is clearly reflected in household and commercial consumption and are those who benefit from different segments of consumption while agricultural and industrial consumption has a single slice [13], [14].

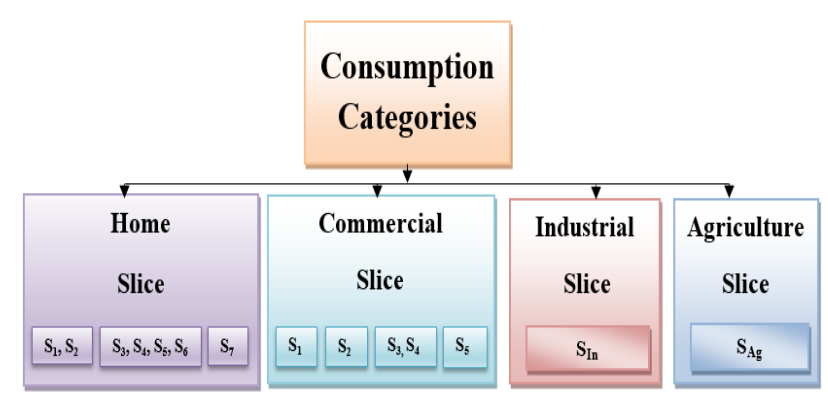

Figure 5. Consumption category slices

According to the Electricity Regulatory Authority and Consumer Protection Regulatory Authority. Common classification of the average energy consumption for home has been listed in Table 3

Table 3. The summarized value of monthly home electrity bill

\begin{tabular}{llllllll}
\hline Consumption Kw & \multirow{2}{*}{ None } & \multicolumn{2}{l}{ Low $(1-100) \mathrm{L}_{\mathrm{L}}\left(\mathrm{S}_{1}, \mathrm{~S}_{2}\right)$} & \multicolumn{2}{l}{ Normal $(1-1000)$ for $>100 \mathrm{~L}_{\mathrm{N}}\left(\mathrm{S}_{3}, \mathrm{~S}_{4}, \mathrm{~S}_{5}, \mathrm{~S}_{6}\right)$} & \multicolumn{1}{l}{$\mathrm{High}>1000$} \\
$\mathrm{~L}_{\mathrm{H}}\left(\mathrm{S}_{7}\right)$
\end{tabular}

The customer consumption is usually located between seven slices of table 3 , these slices are divided into three separate levels; low, normal and high. The low level has couple of slices $S_{1 L}$ and $S_{2 L}$, 
normal level includes quad slices $S_{3 N}, S_{4 N}, S_{5 N}, S_{6 N}$ while single slices for highest single level $S_{7 H}$. This of course is depending on the user consumption. When the total consumption is $200 \mathrm{Kw}$ then the bill value is 78 EGP, at $650 \mathrm{Kw}$ consumption the bill will be 462 EGP.

\section{CUSTOMER CONSUMPTION CALAULATION}

Assuming the total home consumption is $\mathrm{C}_{\mathrm{T}}$ (Kw/Month), the slide number consumption is $\mathrm{S}_{\mathrm{s}}$, the slide consumption is $C_{s}(K w)$, the $K w$ (Egyptian Pound) price is $P_{s}$, customer service price for slice is $R_{s}$ (Egyptian Pound), low level consumption is $\mathrm{L}_{\mathrm{L}}$, normal level consumption is $\mathrm{L}_{\mathrm{N}}$, high level consumption is $\mathrm{L}_{\mathrm{H}}, \mathrm{T}_{\mathrm{S}}$ is the total slice consumption (Egyptian Pound), $\mathrm{M}_{\mathrm{S}}$ total slice consumption EGP and $\mathrm{P}_{\mathrm{T}}$ is the total customer consumption (Egyptian Pound) can be obtain as in following (1). Electrity bill value calculation as shown in Figure 6.

$$
\mathrm{P}_{\mathrm{T}}=\sum_{1}^{s-1}(\mathrm{C} * \mathrm{P})+\left\{\left(\mathrm{C}_{\mathrm{T}}-\mathrm{M}_{\mathrm{C}-1}\right) * \mathrm{P}_{\mathrm{s}}\right\}+\mathrm{R}_{\mathrm{s}}
$$

Moreover, the customer consumption can be calculated by (2)

$$
\mathrm{P}_{\mathrm{T}}=\mathrm{T}_{\mathrm{s}-1}+\left\{\left(\mathrm{C}_{\mathrm{T}}-\mathrm{M}_{s-1}\right) * \mathrm{P}_{s}\right\}+\left(\mathrm{R}_{s}-\mathrm{R}_{s-1}\right)
$$

\subsection{Case Study}

For example, the home customer consumption $\mathbf{C}_{\mathbf{T}}$ is $90(\mathrm{Kw} / \mathrm{Month})$ can be analyzed and cost calculated using (1) \& (2) as follows.

The total consumption $\mathbf{C}_{\mathbf{T}} 90 \mathrm{Kw} / \mathrm{month}$ should be reviewed to Table 3 for determined the level and slice $\mathbf{S}_{\mathbf{s}}$; then found this consumption in low level consumption $\mathbf{L}_{\mathbf{L}}$ and in the second slice. $\mathbf{S}_{\mathbf{2}}$

In case of (1) one can sustitute with following parameter:

$\mathrm{C}_{\mathrm{T}}=90 \mathrm{Kw}, \mathrm{S}=2, \mathrm{~S}-1=1$, Sum. $1, \mathrm{C}=\mathrm{C}_{1}=50 \mathrm{Kw}, \mathrm{P}=\mathrm{P}_{1}=0.22 \mathrm{EGP}, \mathrm{T}_{\mathrm{C}-1}=\mathrm{T}_{1}=50 \mathrm{Kw}, \mathrm{P}_{\mathrm{S}}=\mathrm{P}_{2}=0.30$

$\mathrm{EGP}, \mathrm{R}_{\mathrm{S}}=\mathrm{R}_{2}=2 \mathrm{EGP}, \mathrm{T}_{\mathrm{S}-1}=\mathrm{T}_{1}=12 \mathrm{EGP}$ and $\mathrm{M}_{\mathrm{S}-1}=\mathrm{M}_{1}=50 \mathrm{Kw}$.

Thin:

$\mathrm{P}_{\mathrm{T}}=\left(\mathrm{C}_{1} * \mathrm{P}_{1}\right)+\left\{\left(\mathrm{C}_{\mathrm{T}}-\mathrm{M}_{1}\right) * \mathrm{P}_{2}\right\}+\mathrm{R}_{2}$

$(50 * 0.22)+\{(90-50) * 0.30\}+2=25$ EGP

The total bill value of $90 \mathrm{Kw} / \mathrm{month}$ home consumption is 25 EGP.

Or sustitute in (2):

Then:

$\mathrm{P}_{\mathrm{T}}=\mathrm{T}_{1}+\left\{\left(\mathrm{C}_{\mathrm{T}}-\mathrm{M}_{1}\right) * \mathrm{P}_{2}\right\}+\left(\mathrm{R}_{2}-\mathrm{R}_{1}\right)$

$12+\{(90-50) * 0.30\}+(2-1)=25$ EGP

The total bill value of $90 \mathrm{Kw} / \mathrm{month}$ home consumption is $25 \mathrm{EGP}$.

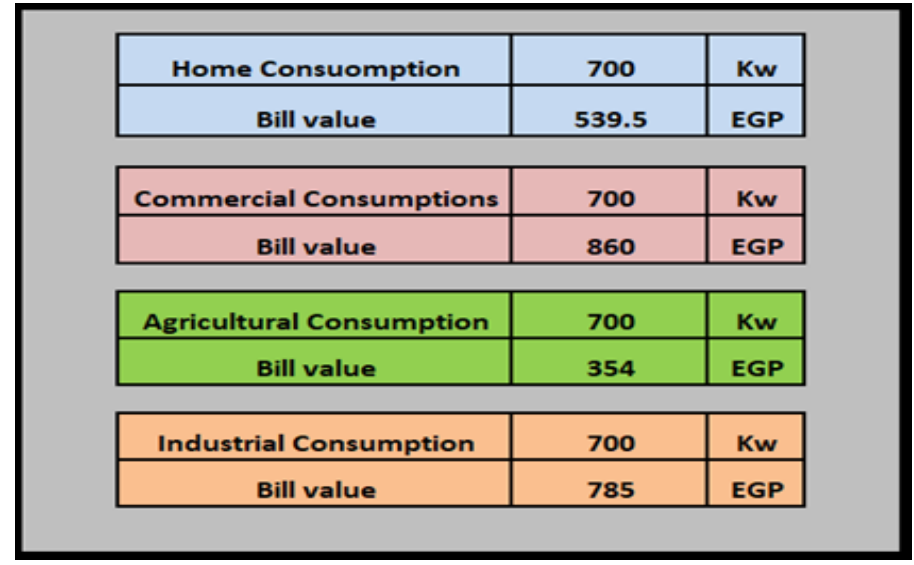

Figure 6. Electrity bill value calculation 


\section{BILLS CALCULATOR}

The following program is a quick calculation for Bill value as in Figure 4. Just input the total cousumption data in $\mathrm{Kw}$ and type of consumption to get the total value of the bill in EGP. Consumption of $700 \mathrm{Kw}$ For example, the invoice value varies according to the type of residential is $539.5 \mathrm{EGP}$, commercial is 860 EGP, agricultural is 354 EGP or industrial be 785 EGP consumption as shown in Figure 6.

\section{LOCALIZED PERSONAL HOME SOLAR SYSTEM ESTIMATIN.}

Quick and simple calculation for the basic energy, consumption of the economical residential can be discussed as follows basic an apartment units (section). An apartment of single room should include kitchen, bathroom, common areas and many balconies. The apartment can be extended to include several rooms as well as more than one bathroom. However, the apartment power consumption can be estimated a cording to the flowchart of Figure 7.

This estimated consumption power the solar system (panels, charge controller, batteries bank and the inverter) are opted based overall cost of the solar system will be also determined using the estimator.

\begin{tabular}{|c|c|c|c|c|c|c|c|c|}
\hline \multicolumn{6}{|c|}{ Quick estimation for solar system } & \multirow[b]{2}{*}{ Power System } & \multirow[b]{2}{*}{15.2} & \multirow[b]{2}{*}{$10^{3}$ Watt } \\
\hline Building & No. & \multicolumn{2}{|l|}{ Unit Description } & Meter $^{2}$ & $\mathrm{~m}^{2}$ & & & \\
\hline No. of unit $20 \mathrm{~m}^{2}$ & 1 & (living room + Bathroom) & $\approx$ & 20 & $\mathrm{~m}^{2}$ & & & \\
\hline No. of unit $63 \mathrm{~m}^{2}$ & 0 & (Bedroom + living room + Kitchen + Bathroom) & $z$ & 63 & $\mathrm{~m}^{2}$ & Solar panel & 37.073 & $410 \mathrm{w}$ for eatch \\
\hline No. of unit $70 \mathrm{~m}^{2}$ & 0 & (2 Bedroom + living room + Kitchen + Bathroom) & $\approx$ & 70 & $\mathrm{~m}^{2}$ & Inverter & 15.2 & kw \\
\hline No. of unit $90 \mathrm{~m}^{2}$ & 0 & (2 Bedroom + 2 living room + kitchen + Bathroom) & $\approx$ & 90 & $\mathrm{~m}^{2}$ & charge controlle & 15.094 & Amper \\
\hline No. of unit $106 \mathrm{~m}^{2}$ & 0 & (3 Bedroom + 2 living room + kitchen + Bathroom) & $\approx$ & 106 & $\mathrm{~m}^{2}$ & Battaries & 15.094 & Amper/Hr \\
\hline No. of unit $130 \mathrm{~m}^{2}$ & 0 & (3 Bedroom + 2 living room + kitchen +2 Bathroom) & $z$ & 130 & $\mathrm{~m}^{2}$ & & & \\
\hline No. of unit $160 \mathrm{~m}^{2}$ & 0 & (3 Bedroom + 3 living room + kitchen +2 Bathroom) & $\approx$ & 160 & $\mathrm{~m}^{2}$ & Total Price & 258.4 & $10^{3} \mathrm{EGP}$ \\
\hline No. of unit $170 \mathrm{~m}^{2}$ & 2 & (3 Bedroom + 3 living room + kitchen +3 Bathroom) & $z$ & 170 & $\mathrm{~m}^{2}$ & \multirow{3}{*}{\multicolumn{3}{|c|}{ Normal control voltage for system $1000 \mathrm{dcv}$}} \\
\hline No. of unit $200 \mathrm{~m}^{2}$ & 2 & (4 Bedroom +3 living room + kitchen +3 Bathroom) & $z$ & 200 & $\mathrm{~m}^{2}$ & & & \\
\hline No. of unit $240 \mathrm{~m}^{2}$ & 0 & (4 Bedroom + 4 living room + kitchen +3 Bathroom) & $z$ & 240 & $\mathrm{~m}^{2}$ & & & \\
\hline 15.2 & Natt & stimation of solar system in watt for Buildin & & & & & & \\
\hline 258.4 & ${ }^{3}$ EGP & Iding & & & & & & \\
\hline
\end{tabular}

Figure 7. Solar system price and specs

When have a building consists of 2 units $170 \mathrm{~m}^{2}$ each, 2 units $200 \mathrm{~m}^{2}$ each and one-unit $20 \mathrm{~m}^{2}$ for doorman then the solar system which we need to overcome this building is $15.2 \mathrm{KW}$ and its price be 258,400 EGP.Starting current for motors and compressors is an important concept in this design.

\section{CONCLUSIONS}

A cost and non-interruptible optimized hybrid solar-grid system has been proposed, simulated and realized. The system offerred the possibility of working with ON/OFF grid. The maximum permissible extracted energy from solar cells is one of the system features. Actual sustainability has been experimentally accomplished where the battery bank was designed to cover the daily load requirements. The system ATS is configured for an automatic navigation between manual or automated switching. The system has been modeled, implemented and tested using the Matlab Simulink packages. Two years, the electricity bills have been attached and compared with the photovoltic output meters. A cost and non-interruptible optimized hybrid solar-grid system has been proposed, simulated and realized.

Then get the following:

a. $35 \%$ reduction has been gained according to the official bills.

b. The system offered the possibilities of working in parallel with grid.

c. The maximum permissible extracted energy from solar cells is one of the design criteria.

d. Actual sustainability and satisfactory agreement have been experimentally fulfilled.

e. The programmable system ATS has been configured for an automatic navigation between manual or automated switching.

f. A clear cost reduction of the supported public grid electricity. 


\section{REFERENCES}

[1] Hui, Joanne, Alireza Bakhshai, and Praveen K. Jain., "A hybrid wind-solar energy system: A new rectifier stage topology," in Applied Power Electronics Conference and Exposition (APEC), 2010 Twenty-Fifth Annual IEEE, pp. 155-161, 2010.

[2] Ye, Shunliu, and Bo Sun., "Application of flywheel battery in solar power system," in Energy and Environment Technology, 2009. ICEET'09. International Conference on, vol. 1, pp. 533-536. IEEE, 2009.

[3] Fluri, Thomas P, "The potential of concentrating solar power in South Africa." Energy Policy 37, no. 12 : 5075-5080, 2009.

[4] Chan, Ngai Lam Alvin., "Solar electricity from concentrator photovoltaic systems," 2013.

[5] IEA. Energy technology transitions for industry: strategies for the next industrial revolution. OECD Publishing, 2009.

[6] Dali, Mehdi, Jamel Belhadj, and Xavier Roboam, "Hybrid solar-wind system with battery storage operating in grid-connected and standalone mode: control and energy management-experimental investigation," Energy 35, no. $6: 2587-2595,2010$.

[7] Carrasco, Juan Manuel, Leopoldo Garcia Franquelo, Jan T. Bialasiewicz, Eduardo Galván, Ramón Carlos PortilloGuisado, MA Martin Prats, José Ignacio León, and Narciso Moreno-Alfonso, "Power-electronic systems for the grid integration of renewable energy sources: A survey," IEEE Transactions on industrial electronics 53, no. 4 : 1002-1016, 2006.

[8] National Research Council. Restructuring federal climate research to meet the challenges of climate change. National Academies Press, 2009.

[9] Lyman, R. O. B. E. R. T., and ENERGY ECONOMIST, "Why renewable energy cannot replace fossil fuels by 2050," Friends of Science Calgary, 2016.

[10] Kearney, David, "Utility-scale power tower solar systems: Performance acceptance test guidelines," Contract 303 : 275-3000, 2013.

[11] Wong, S. Y., and A. Chai, "An off-grid solar system for rural village in Malaysia," In Power and Energy Engineering Conference (APPEEC), 2012 Asia-Pacific, pp. 1-4, 2012.

[12] Arafa, M. I. A., Said, E. S. S. A., \& Elwany, M., "An optimized design criteria of non-outage and power reduction for hybrid solar-grid system (residential homes - case study). In Power Systems Conference (MEPCON), 2017 Nineteenth International Middle East (pp. 59-62). IEEE, 2017, December.

[13] Yogianto, Agus, Hendra Budiono, and Indra A. Aditya, "Configuration hybrid solar system (PV), wind turbine, and diesel," in Power Engineering and Renewable Energy (ICPERE), 2012 International Conference on, pp. 1-5, 2012.

[14] Nan, Jiang, and Xu Honghua, "Detection platform design of solar energy grid-connected photovoltaic system," in Power System Technology (POWERCON), 2010 International Conference on, pp. 1-4, 2010.

[15] Almi, M. F., et al., "Energy management of wind/PV and battery hybrid system," International Journal of New Computer Architectures and their Applications (IJNCAA), 4.1: 30-38, 2014.

[16] Zhang, Li, et al., "A family of neutral point clamped full-bridge topologies for transformerless photovoltaic gridtied inverters," IEEE Transactions on Power Electronics 28.2: 730-739, 2013. 